DISINTEGRATING DEMOCRACY AT WORK 


\section{DISINTEGRATING DEMOCRACY}

\section{AT WORK}

\section{Labor Unions and the Future of Good Jobs in the Service Economy}


Copyright $\odot 2012$ by Cornell University

All rights reserved. Except for brief quotations in a review, this book, or parts thereof, must not be reproduced in any form without permission in writing from the publisher. For information, address Cornell University Press, Sage House, 512 East State Street, Ithaca, New York 14850.

First published 2012 by Cornell University Press

Printed in the United States of America

Library of Congress Cataloging-in-Publication Data

Doellgast, Virginia Lee, 1976-

Disintegrating democracy at work : labor unions and the future of good jobs in the service economy / Virginia Doellgast.

p. cm.

Includes bibliographical references and index.

ISBN 978-0-8014-5047-1 (cloth : alk. paper)

1. Call centers-United States. 2. Call centers-Germany.

3. Telecommunication-Employees-Labor unions-United

States. 4. Telecommunication-Employees-Labor unions-

Germany. 5. Service industries workers-Labor unions-United

States. 6. Service industries workers-Labor unions-Germany.

7. Industrial management-Employee participation-United

States. 8. Industrial management-Employee participation-

Germany. I. Title.

HE8789.U6D64 2012

331.88' 11000943-dc23 2011031367

Cornell University Press strives to use environmentally responsible suppliers and materials to the fullest extent possible in the publishing of its books. Such materials include vegetable-based, low-VOC inks and acid-free papers that are recycled, totally chlorine-free, or partly composed of nonwood fibers. For further information, visit our website at www.cornellpress.corneIl.edu.

$\begin{array}{lllllllllll}\text { Cloth printing } & 10 & 9 & 8 & 7 & 6 & 5 & 4 & 3 & 2 & 1\end{array}$ 


\section{CONTENTS}

Preface vii

Acknowledgments xiii

List of Abbreviations $\quad$ xvii

1. Introduction 1

2. Changes in Markets and Collective Bargaining 28

3. Using Power in the Workplace 54

4. Losing Power in the Networked Firm 122

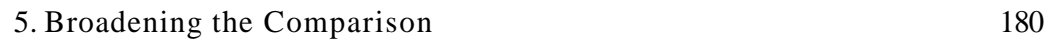

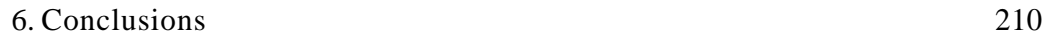

Appendixes

A Interviews conducted in the United States and Germany 221

B Organizational characteristics and employment practices by country, in-house and outsourced centers 


\section{Contents}

C Organizational characteristics and employment practices by collective bargaining arrangements, United States and Germany

Notes

Bibliography

Index 


\section{PREFACE}

Labor unions across the global North are struggling to improve pay and working conditions in expanding service sector industries. This is by no means an easy task. The workplaces of the new economy remain poorly organized. Even in European countries known for their corporatist political traditions, politicians are designing new legislation intended to break the grip of strong labor laws and employment protections on a stagnant economy. Worker representatives find their role in national policymaking and in corporate decision making weakened at a time when more insecure, lower-paid jobs are expanding.

This book is about the role that labor unions can and should play in modern service workplaces. Its central motivating question is whether strong and cooperative industrial relations institutions characteristic of social Europe have the potential to give service workers similar benefits to those achieved in the golden age of postwar manufacturing: productive and stable employment characterized by high job quality and low wage inequality. Past academic and policy debates on the relationship between 
national institutions, management strategies, and worker outcomes have focused overwhelmingly on large export-oriented sectors such as the global auto industry. Institutions in most service industries look a lot less coherent than those described in these accounts. Union membership and works council presence are much lower in services than in manufacturing. Service workers are also less likely to be covered by a union contract or to have traditional occupational training, and their jobs tend to be lower paid and less secure.

As these poorly regulated service jobs become more typical of where Americans and Europeans work, the questions comparative researchers asked in auto assembly plants and steel mills need to be revisited. Is there an inevitable convergence on one "best practice" employment model, as managers adjust to competition unfettered by laws or unions? Or does context matter, even in more peripheral workplaces: Do different laws and collective bargaining arrangements make a difference for management strategies and employee outcomes? What influence do these strategies have, in turn, on the strength and coverage of collective bargaining? These questions are at the heart of debates over the future of work and worker welfare in increasingly interconnected, postindustrial economies.

I attempt to answer these questions here through the lens of a comparative study carried out in U.S. and German call centers. The analysis looks at how unions and works councils have shaped employer strategies to restructure these easily rationalized service jobs, and how these strategies have in turn refashioned industrial relations institutions. My focus is on industrial relations rather than other institutions, such as vocational training or corporate governance. While collective bargaining is only one part of broader systems of rules and incentives at the national level, it is unique in regulating the balance of power in the workplace and in laying out the conditions under which employees can participate in management decision making. Empirical findings are drawn largely from two industry sectors: telecommunications, which continues to have strong unions in many countries, and the third-party call center industry, which is a newer sector made up of firms with weaker or no unions that often perform subcontracted call center work for telecommunications firms. In both sectors, I examine the changes that occurred in the organization of call center jobs during the 1990s and 2000s, following the liberalization of U.S. and German telecommunications markets. 
Call centers are in many ways the ideal setting for examining how institutions affect management strategy and worker outcomes in postindustrial economies. They are among the most highly mobile of service workplaces, with jobs that are increasingly easy to outsource and that are often viewed as peripheral to firms' "core competencies." In many countries, governmentdriven liberalization of service markets has increased pressure on managers to cut labor costs for these jobs. For all of these reasons, call centers are workplaces where we might most expect to see convergence on weak collective bargaining institutions and a management model based on reducing costs rather than investing in job quality. For these same reasons, they are a good place to look for the causes of past and continued divergence in management strategy and worker outcomes.

The dynamics of growing competition, organizational restructuring, and erosion of industry-level bargaining are hardly unique to call centers. In this sense, they are typical of a range of easily rationalized jobs in growing, poorly regulated industries. If unions can make a difference for management strategy in these workplaces, there is strong evidence for the continued relevance of national industrial relations institutions in the regulation of employment. Evidence of their failure to improve or maintain working conditions likewise suggests the need for more careful study of the causes of these failures and their labor market consequences.

During my field research in the United States and Germany, I observed a number of differences in how call centers were managed. German call center agents generally were paid higher salaries and had more control over their work than those in the United States. They were more likely to be treated like professionals, with flexible schedules and rules that protected them from the kind of invasive electronic monitoring that was common in U.S. centers. However, the most striking differences concerned the process of management decision making, and the effects that this had on employment practices. In Germany, independent works councils participated in democratic consultation and negotiation over these decisions. Worker representatives used their strong participation rights to help managers find compromise solutions that reduced costs and improved productivity and service quality, while ensuring that the privacy, dignity, and economic interests of the workforce were respected. Meanwhile, U.S. unions struggled to enforce the limited terms of the collective agreements that they were able to negotiate, against an often hostile management. 
Where unions were not present, pressures to cut costs and the easy fix of new technologies seemed to leave managers with little choice but to intensify monitoring and discipline on a low-wage, high-turnover workforce.

The different practices and outcomes in these workplaces could thus be more or less directly traced to institutions that gave worker representatives widely diverging participation rights and bargaining power. German codetermination rights, exercised by strong and independent works councils, proved to be a crucial support for alternative, high-involvement employment systems-even in easily rationalized service jobs. Put another way, strong institutional supports for workplace democracy pushed call center managers to take the high road in workplaces where there were many incentives to reduce pay and rationalize work.

At the same time, I also found that worker representatives were facing formidable challenges to maintaining these institutions. In both the United States and Germany, the number of call center jobs in workplaces with strong unions was shrinking. Market liberalization and technological change meant that telecommunications employers faced growing price competition in increasingly volatile markets. They responded by developing similar organizational strategies that downgraded pay and working conditions through moving work to subcontractors and subsidiaries. Employers then renegotiated pay at lower levels or simply shifted calls wholesale to companies with weaker collective agreements. These trends were weakening coordinated collective bargaining and undermining unions' and works councils' bargaining power.

Based on these findings, I argue that institutional supports for workplace democracy and for the maintenance or extension of encompassing collective bargaining are essential for encouraging high-road practices where there are strong countervailing pressures to cut costs. Managers have a range of different incentives to invest in skills and employee discretion in workplaces servicing value-added market segments. In the service workplaces studied here, variation in the ability of workers to participate substantively in management decisions was a critical factor explaining why some call centers adopted high-involvement employment systems and others did not. This ability to participate in democratic arrangements depended, in turn, on legal participation rights and bargaining structures, which influenced worker representatives' countervailing power in negotiations with management. 
One objective in this book is to bring this political dimension of management strategy and practice back to the center of debates over contemporary change in national models. Comparative theorists often treat strategy and institutions as coherent bundles or systems. Taylorism, diversified quality production, and high performance work systems are by now wellknown ideal type production models. They have most often been studied for their promise to improve firm performance, albeit through more or less worker-friendly practices. Analyses of hybridization of these models describe the mechanisms through which institutional change occurs based on increasingly complex categories of complementary institutions and their relationship with firms' strategic choices.

This focus on firm strategies in much of the comparative literature neglects the negotiations and conflicts that accompany changes in work organization, as well as their concrete effects-in the short term, on pay and working conditions; and in the longer term on bargaining power and institutions. While worker participation undeniably can produce benefits for firms, it has also traditionally been resisted by managers seeking to reduce costs or expand their own scope to implement new strategies unilaterally. An important question is under what conditions worker representatives are able to encourage qualitatively different employment models that produce some possibility of "mutual gains," in settings where their own power or scope for maneuver is changing. To answer this question, it is necessary to take a closer look at how negotiations over restructuring play out in those firms and workplaces that face the most intense pressures to rationalize jobs and lower wages. By unbundling strategy, institutions also begin to look more like heterogeneous resources that unions can draw on to effect meaningful changes in pay and working conditions.

A further objective is to more closely examine the social costs of market liberalization, or what is lost as collective bargaining becomes increasingly disorganized and as unions lose power and influence. In the past, the social market countries of continental Europe were held up as representing an alternative model to free market or liberal capitalism, with political and economic institutions that ensured the benefits of economic growth were more broadly distributed. Strong labor market regulations and powerful labor unions encouraged employers to invest in high wages and worker skills, while supporting competitive advantage in more value-added segments of global markets. Labor unions in Europe played a leading role in 
promoting quality of working life as a central principle in work design, encouraging managers to invest in expanded job discretion and worker participation at a time when similar U.S. companies were cutting costs and downsizing.

Today, inequality is also on the rise in social Europe. Governments are deregulating their labor markets to encourage job growth and unions are declining in power and influence. Germany was long the best-practice case of a national economy that managed to compete in global markets on the basis of well-engineered, quality products, while distributing the benefits of value-added production more broadly across the workforce. In contemporary Germany, wages are stagnating and low-wage and precarious forms of employment have increased, while firms are reorienting their strategies to better pursue shareholder value.

This book draws on the experiences of the individuals and organizations who are both driving institutional change and experiencing the costs of more flexible labor markets, changing organizational boundaries, and weakened unions. The accounts of the workers, managers, works councilors, and union representatives interviewed in the course of this study give insights into the social and strategic advantages of the kind of workplace democracy that was (and to some degree still is) characteristic of the textbook "German Model." Strong codetermination institutions support deliberation over the goals and practices that firms adopt when faced with similar market challenges. In the cases presented here, these institutions gave works councils the tools to propose and enforce alternatives to rationalization and intensified monitoring. The loss of this power has had devastating consequences for employees and has created new kinds of management problems for their employers. A closer examination of the politics of restructuring helps us better understand these consequences and their causes. 


\section{ACKNOWLEDGMENTS}

This book is the product of many years of research, starting with my $\mathrm{Ph}$.D. studies at Cornell University and continuing through rounds of follow-up interviews, data analysis, and successive redrafting in the five odd years since. In this time, I have accumulated an extensive debt to many colleagues and institutions who provided support along the way.

The union representatives, works councilors, managers, and employees who explained their work and organizations to me are too numerous to list here (and because of promises of anonymity many cannot be listed). In the United States, Debbie Goldman, Beverly Hicks, Annie Hill, Robert Patrician, Teri Pluta, and Pat Telesco at the CWA answered numerous followup questions, and gave valuable feedback on written drafts. In Germany, Siegfried Balduin at IG Metall and Otmar Diirotin, Christoph Heil, Sylva Hieckman, Frank Sauerland, Hans-Juergen Klempau, and Ado Wilhelm at ver.di explained evolving developments in the industry (some of them over many follow-up interviews) and provided contacts at case study companies. Wittich Rossman from IG Metall helped me to develop a more 
intuitive understanding of "Rheinland style" social partnership. Agnes Schreieder provided much patient tutelage on ver.di's internal politics and the difficulties of organizing low-wage workplaces in Germany. In addition, librarians at the Hans Bockler Stiftung and ver.di assisted with archival research over the course of several research trips.

My colleagues in the Global Call Center Project have been an important source of contacts and ideas. Ursula Holtgrewe and Karen Shire helped me to figure out what was particularly interesting about call centers in Germany, and then integrated me into their research team and generously shared their survey data. Frank Kleeman and Ingo Matuschek encouraged my developing research plan (and German language skills) during my stay in Chemnitz. Ingo invited me along for several week-long research trips at Deutsche Telekom, which provided data and insights that became the core of this study. I owe Ingo and Ursula special thanks for sharing copious interview notes from their past research projects in German call centers. Members of the other country teams gave valuable feedback during several working conferences and contributed insights from their own research. My more recent work with Hiroatsu Nohara and Robert Tchobanian on a comparison of the French and German telecommunications industries helped me to better understand the distinctiveness of the German case and is the basis for the French case study in chapter 5 of this book. My work with Ole SOrensen editing a special journal issue on call centers in Europe was also useful in developing the ideas and analysis in that chapter, particularly concerning the interpretation of developments in Danish call centers.

Many institutions provided financial and logistical support. My Ph.D. field research in Germany was funded by a Fulbright Fellowship, small grants from the Einaudi Center and the Benjamin Miller Scholarship Fund at Cornell, and a grant from the Council of European Studies. My field research in the United States was conducted while I was working as a research assistant on the Cornell-Rutgers Telecommunications Project, supported by the Alfred P. Sloan Foundation; and the Global Call Center Project, supported by the Russell Sage Foundation. Both foundations funded the U.S. call center survey. The German call center survey was supported by a grant from the Hans Bockler Stiftung. Other surveys in the Global Call Center Project were supported by a range of funding bodies (see www.ilr.cornell.edu/globalcallcenter/sponsors/). Giinter Voss hosted 
me at the Technische Universitat Chemnitz during the first month of my research year in Germany, providing a useful introduction to East Germany. Wolfgang Streeck at the Max Planck Institut fur Gesellschaftsforschung in Cologne gave me the opportunity to enjoy the institute's excellent office and research facilities during the remainder of my stay, as well as to participate in seminars and lectures with a thoughtful community of scholars. Discussions with Martin Hopner, Till Miiller-Schoell, Myung-Joon Park, Britta Rehder, Christine Trampusch, and Josh Whitford helped with thinking through the research design and interpretation of findings. At Cornell, Marco Hauptmeier, Rob Hickey, Hyunji Kwon, Julie Sadler, and Danielle van Jaarsveld gave feedback and support during many doctoral seminars and discussions.

In the years since completing my Ph.D., I was able to conduct followup research in Germany with the help of funding from King's College London and the London School of Economics. I worked on parts of this book manuscript while a visiting scholar at the Wissenschaftszentrum Berlin (WZB), the University of New South Wales, and the Laboratoire d'Economie et de Sociologie du Travail (LEST). Arndt Sorge, Steve Frenkel, and Ariel Mendez were gracious hosts during these visits, and seminars at each institute were useful in figuring out what was particularly interesting in my research findings for an international audience of scholars.

My advisors and colleagues have provided valued mentoring and support throughout. Katherine Stone, Lowell Turner, and Sarosh Kuruvilla gave feedback on early proposals and drafts. My committee members John Bunge, Susan Christopherson, and Harry Katz helped with data analysis and interpretation of findings. Rose Batt deserves a special heartfelt thanks for her support during my Ph.D. studies and in the years since. This book benefited enormously from her detailed feedback on research design, interpretation, and through several stages of writing. Lowell, Harry, Rose, Chris Tilly, and Pat McGovern all read and commented on recent drafts of the book manuscript, providing useful suggestions for revisions. My colleagues at King's College London and London School of Economics helped to sharpen my analysis through feedback on a series of articles based on this research, including Olivier Butzbach, Tony Edwards, Howard Gospel, David Guest, Richard Hyman, Gregory Jackson, David Marsden, Riccardo Peccei, and Matt Vidal. 
Several chapters in this book draw on previously published material. Chapter 2: Virginia Doellgast, "Still a Coordinated Model? Market Liberalization and the Transformation of Employment Relations in the German Telecommunications Industry," Industrial and Labor Relations Review 63(1) (2009): 3-23. Chapter 3: Virginia Doellgast, "Collective Voice under Decentralized Bargaining: A Comparative Study of Work Reorganization in US and German Call Centres," British Journal of Industrial Relations 48(2) (2010): 375-99. Chapter 4: Virginia Doellgast, "National Industrial Relations and Local Bargaining Power in the US and German Telecommunications Industries," European Journal of Industrial Relations 14(3) (2008): 265-87. Chapter 5: Virginia Doellgast, Hiroatsu Nohara, and Robert Tchobanian, "Institutional Change and the Restructuring of Service Work in the French and German Telecommunications Industries," European Journal of Industrial Relations 15(4) (2009): 373-94.

A conversation with Fran Benson at Cornell University Press five years ago planted the idea that my Ph.D. research could be turned into a book. She gave much valued support to this project during the past year, as I set out to write that book. The copyediting of Jack Rummel and production work of Karen Laun significantly improved the clarity of the text.

Finally, I owe a big debt to my family. My husband, Ian, has been a true partner during the research and writing of this book, first encouraging me to take an interest in German industrial relations; and then serving as my best sounding board and critic for numerous ideas and drafts. My mother, Janet, enthusiastically supported my studies and work, even when they took me far from home; while my father, George, shared his wisdom accumulated from years as an academic. He was particularly pleased when I decided to study in Germany, to which he felt a close connection through his German parents and the immigrant community in New York where he grew up. His death two years ago was a great loss. This book is dedicated to him. 


\section{ABBREVIATIONS}

BDA Bundesvereinigung der Deutschen Arbeitgeberverbande (Confederation of German Employers)

CFDT Confederation franchise democratique du travail (French Democratic Confederation of Labour)

CGPT Christliche Gewerkschaft Post und Telekommunikation (Christian Postal and Telecommunications Union)

CGT Confederation generale du travail (General Confederation of Labor

CLEC Competitive local exchange carrier

CTI Computer Telephony Integratio CWA Communications Workers of America

DBP Deutsche Bundespost

DGB Deutscher Gewerkschaftsbund (Confederation of German Trade Unions)

DPG Deutsche Postgewerkschaft (German Postal Union)

DPV Kom Kommunikationsgewerkschaft DPV (Communications union DPV) 


\begin{tabular}{|c|c|}
\hline XVlll & Abbreviations \\
\hline DT & Deutsche Telekom \\
\hline FMLA & Family Medical Leave Act \\
\hline HB V & $\begin{array}{l}\text { Gewerkschaft Handel, Banken und Versicherung (Retail, } \\
\text { Banking, and Insurance Union) }\end{array}$ \\
\hline IBEW & International Brotherhood of Electrical Workers \\
\hline IGBCE & $\begin{array}{l}\text { Industriegewerkschaft Bergbau, Chemie und Energie (Min- } \\
\text { ing, Chemicals, and Energy Union) }\end{array}$ \\
\hline IG Metall & Industriegewerkschaft Metall (Metalworkers Union) \\
\hline ILEC & Incumbent local exchange carrier \\
\hline ISDN & Integrated Services Digital Network \\
\hline ISP & Internet Service Provider \\
\hline $\mathrm{MCO}$ & Mannesmann Customer Operations \\
\hline $\mathrm{NDA} / \mathrm{CA}$ & National Directory and Customer Assistance \\
\hline NL & Niederlassung (Region) \\
\hline NLRB & National Labor Relations Board \\
\hline OGB & $\begin{array}{l}\text { Osterreichische Gewerkschaftsbund (Confederation of } \\
\text { Austrian Unions) }\end{array}$ \\
\hline OTV & $\begin{array}{l}\text { Gewerkschaft offentliche Dienste, Transport und Verkehr } \\
\text { (Public Service, Transport, and Traffic Union) }\end{array}$ \\
\hline PSA & Personal Service Agentur \\
\hline PUC & Public Utilities Commission \\
\hline $\mathrm{RBOC}$ & Regional Bell Operating Company \\
\hline SEC & Securities and Exchange Commission \\
\hline SUD & $\begin{array}{l}\text { Solidaires, Unitaires, Democratiques (Solidaristic, United, } \\
\text { Democratic) }\end{array}$ \\
\hline TIM & $\begin{array}{l}\text { Telekommunikation, Informationstechnologie, Medien (Tele- } \\
\text { communications, Information Technology, Media) }\end{array}$ \\
\hline T K G & Telekommunikationsgesetz (Telecommunications Act) \\
\hline UNETEL & $\begin{array}{l}\text { Union Nationale des Entreprises de Telecommunications } \\
\text { (National Association of Telecommunications Employers) }\end{array}$ \\
\hline UNI & Union Network International \\
\hline VCS & Vivento Customer Services \\
\hline $\begin{array}{l}\text { VDSL } \\
\text { ver.di }\end{array}$ & $\begin{array}{l}\text { Very High Speed Digital Subscriber Line } \\
\text { Vereinte Dienstleistungsgewerkschaft (United Service Sector } \\
\text { Union) }\end{array}$ \\
\hline VoIP & Voice over IP \\
\hline WPOF & Workplace of the Future Agreement \\
\hline
\end{tabular}


DISINTEGRATING DEMOCRACY AT WORK 


\section{INTRODUCTION}

Ronald Dore begins his book British Factory, Japanese Factory with the statement, "Factories look very much alike anywhere..." One could easily make the same observation about call centers, often described as the assembly lines of the information age.' Call center agents use the same tools regardless of what country they are in or task they are performing: a headset, a computer, perhaps reference files and a list of phone numbers. Most call centers are located in large rooms divided into many small cubicles, with slightly larger desks or offices for team leaders and managers. Signs of varying degrees of sophistication, perhaps centrally located, perhaps on the bottom of each agent's computer screen, flash the number of customers on hold. The technology behind these white collar factories is becoming close to identical, as consultants and suppliers sell common platforms for predicting call volumes, routing calls to different agents and centers, and developing scheduling plans.

However, seemingly identical call center workplaces can be entirely different kinds of places to work. Managers use a range of approaches to 
organize these jobs and to motivate employees to sell an ever-expanding number of products while still providing efficient (yet high-quality) customer service. The service companies that operate call centers experiment with performance incentives, different ways of splitting up tasks, and team-based or individualized models of work organization. Some call centers rely heavily on electronic monitoring systems that record every key stroke and conversation, while others use more personalized side-by-side coaching. In the course of my research for this book, I interviewed highly skilled call center agents who had been in their jobs for twenty years, were making solid middle-class salaries, and took a great deal of pride in their work. I also met a good share of low-paid and overworked employees who felt they were trapped in dead-end jobs with little control over their day-to-day work.

The present study attempts to make sense of these differences through asking how national and workplace institutions influence management choices in what seem at first glance to be uniformly lower-skilled and easily rationalized service jobs. Under what conditions will employers adopt highroad, or "high-involvement," employment models in workplaces where there are strong pressures to cut labor costs? Is there evidence of cross-national divergence in these models-and if so, what explains these differences?

Matched case studies of call center workplaces in the United States and Germany provide a first look at the experiences of worker representatives in both countries as they have sought to shape management strategies at the workplace and organizational levels. The first pair illustrates contrasting outcomes from negotiations over work reorganization in two large telecommunication firms. The second shows the increasingly similar challenges unions experience in both countries as a result of the outsourcing strategies adopted by those same firms.

\section{The Diverging Politics of Work Reorganization}

A manager steered me through his service and sales call center at a brisk pace, apologizing for the chaos. I was visiting a former regional Bell company, which had been part of the U.S. monopoly AT\&T/Bell system before divestiture and deregulation in the 1980s. The company was in the midst of restructuring its call center jobs, in response to recent regulatory 
changes that had opened up their regional market to competitionputting pressure on management to cut costs.

That day the company was sponsoring an "international party" to promote international long-distance plans. The large open-plan rooms were decked with streamers and balloons, and supervisors milled around in Hawaiian leis, grass skirts, and African headdresses. Each team had made food and decorated its set of cubicles to represent a different country, giving an eerily festive sheen to an otherwise cavernous white room. The center managers were in the process of judging the teams based on their costumes and level of participation, which seemed to roughly translate into the number of team members who had shown the proper amount of enthusiasm in preparing for the competition. They could expect a material payoff for demonstrating that extra team spirit: the members of the winning team would gain points toward their monthly sales bonus, with the tie breaker going to the team that sold the most international long-distance plans.

A perky team leader told me about the many exciting changes they had put in place in the last few years: "We're really much more about sales now. And that means I have to always come up with new ways to motivate my team." She held up some plastic hands, and showed me how you could shake them together to make a clapping sound "to show employees we appreciate them, that they're doing a great job." As we were talking, one of the center leaders came around to take a team photo. The agents reluctantly got up from their desks and grimaced at the camera as the team leader tried to egg them on: "Come on, smile! Don't look so gloomy, this is a party!" "Honestly," she confided later, "the employees we get today just aren't what they used to be. In my day, we were motivated by doing the job well. Now these kids just come in to make some money, and are out the door next week."

Along with building team spirit and rewarding sales, managers were trying to enforce stricter rules on this more difficult-to-motivate workforce. The company had just adopted a new monitoring policy to catch fraud as employees racked up huge bonuses selling products that customers never ordered. Those who did not make their sales targets were put on progressive discipline, and dismissals for poor performance had skyrocketed. The company had also started hiring private investigators to catch employees who were taking unfair advantage of paid sick leave. "When 
employees see a supervisor come out to a desk with a buggy and empty out that desk, they might think twice next time."

Union representatives complained that these policies combining tough discipline and individual sales incentives were undermining their work. They were processing a constant stream of grievances against unfair dismissals and several attempts at partnership had fallen flat. Moreover, this new high turnover, sales-focused workforce was proving to be difficult to convince to get active in the union. Union representatives felt their ability to influence management decisions or protect workers was restricted to filing grievances, along with regular fights during formal bargaining to keep in place some negotiated rules about how and when managers could monitor performance or change schedules.

"Team spirit" was also the buzzword among managers and team leaders at Deutsche Telekom's service and sales centers. Deutsche Telekom was seeking to adjust to growing competition in Germany's fixed-line markets, where they had only recently lost their monopoly. As at the regional Bell, these changes were accompanied by new pressures to cut costs and compete for customers. "Sales offensives" and competitions had become just as much a part of their new culture. Large posters announced how many DSL and long-distance packages teams had sold each day, and how far they had to go to meet their goal for the week. "Employees can add a mark when they sell something-that helps build team solidarity, gives them the feeling they're moving toward something." The company sponsored special win-back offensives, with prizes or bonuses for the winning team. Team leaders admitted they had gotten the competitive bug as well: "I look and see, ah, this week I'm number three, and last week I was number ten in the rankings, good job!"

Also similar to their counterparts at the former regional Bell, Deutsche Telekom's managers were seeking to transform the culture in their call centers, trying to encourage workers to move from their traditional focus on customer service to more of a sales orientation. They had introduced performance-based pay, were teaching selling techniques, and had set up competitions and prizes. Still, call centers belonging to the two companies looked completely different. There were no clappers, balloons, or streamers at Deutsche Telekom. Employees dressed more professionally and tended to be older, making it difficult to tell the team leaders from the agents. Team leaders discussed their employees respectfully, instead 
of like a parent explaining the challenges of disciplining unruly children. "It is impossible to do this job without the trust of your team. They have a certain expectation of us as well: that we will help them to develop, that we will give them some room to use their skills and not look over their shoulder every minute."

Scratch beneath the surface and these differences widen. While the former regional Bell made heavy use of individual bonuses, all sales incentives at Deutsche Telekom were group based. While the U.S. managers constantly monitored their employees, Deutsche Telekom managers had to rely on "mystery calls" to evaluate service quality and could only report results at the team level. Most striking was how much more control employees had over their work and working time. Disciplining agents for poor performance was extremely difficult, break times were flexible, and "working time accounts" meant employees could take time off when they needed it within certain negotiated boundaries. A joint labor-management committee decided on sales goals, and employees could formally challenge these goals if they believed they were unfair. There was also practically no turnover and minimal fraud.

The Company Principles hung on every wall announcing Deutsche Telekom's goal to match customer orientation and professional service: (1) Quality of life in an open information community; (2) We impress customers through innovative solutions and individual service. In one room, a team leader had put up a Goethe quote: "Es hort doch jeder nur, was er versteht" (Each hears only what he understands). In addition to regular training on selling techniques and product updates, employees and supervisors attended special seminars at the company's training centers to develop "professional competence."

At one point during a site visit, I was standing in the hall with a group of call center agents on a smoke break. I listened to their complaints about the new competitions and incentives, growing pressure to make sales goals, constant reorganization in the company, and downsizing. As in many of my visits to German call centers, the employees were curious about whether I observed any differences in the United States. "What is it like there? Aren't all call centers the same?" I told them that supervisors could listen to agents without their knowledge and fire them for poor performance. Several mouths dropped open. "How can they work under those conditions? Aren't they afraid all the time? Does the works council just let 
that happen?" And then I explained that there are no works councils in the United States and that unions do not have the legal right to block remote monitoring or decide on the appropriate criteria for evaluating performance. This was a revelation for them: workers in the United States did not have codetermination rights even where they had a union. They conceded that while they may have troubles, conditions were probably worse for their American colleagues.

\section{The Converging Politics of Organizational Restructuring}

Upstate New York experienced deindustrialization in the 1970s but is still dealing with the problems associated with job loss and social dislocation. Abandoned factories line the roads and waterfronts in many cities and unemployment is persistently high. Buffalo has gone through changes typical of the region. As employment shifted to services, union density and per capita earnings declined. Call centers moved in to take advantage of attractive government subsidies and a large potential pool of workers.

One of Buffalo's large call center subcontractors, Telespectrum, won a contract in the late 1990s to handle DSL sales and customer service for Verizon. Verizon is a "legacy" telecommunications firm coming out of the former AT\&T and regional Bell monopoly, with a long history of collective agreements with the Communication Workers of America (CWA) and the International Brotherhood of Electrical Workers (IBEW). The unions had been trying to halt or reverse outsourcing at Verizon for years with some limited success but had no wins from organizing campaigns in its subcontractors. The conventional wisdom held that these companies were impossible to organize, as it was too easy to intimidate the workforce with threats of moving call center jobs to another center or region. Union representatives and workers with any experience trying to organize call centers repeated one phrase like a mantra: "It's just a matter of flipping a switch, then those jobs are gone."

However, it seemed like they might have a chance at Telespectrum. The IBEW had a number of unemployed members in Buffalo who were willing to take jobs and organize the workforce at the subcontractor, and the union thought it could use its leverage at Verizon to put pressure 
on management. These union activists organized an election and won union recognition in 2000-the first successful organizing campaign at a U.S.-based call center subcontractor. After fourteen months of difficult negotiations, management agreed to a contract that raised pay 14 percent, from $\$ 8.75$ to $\$ 10$. Although this was still less than half of the average salary in the company's unionized call centers, it was substantially higher than the typical wage for subcontracted jobs. However, three months later, Verizon withdrew its contract with the company and moved the work to several nonunion subcontractors in southern "right to work" states. The call center closed, and three hundred employees lost their jobs.

A similar chain of events unfolded in Siegen, a small city in the German state of Nordrhein-Westfalen, which is the historic center of West German manufacturing. Like many cities in the region, Siegen has shed population over the past decade due to the decline of the steel industry, and has been steadily losing its remaining manufacturing jobs. Abandoned factories line the main highway through town, and unemployment fluctuates around 10 percent. Similar to Buffalo, the local government sought to attract call centers as part of more service sector-focused economic development strategies. In 1999 T-Online, a subsidiary of Deutsche Telekom, set up a technical support call center in Siegen. The company was attracted to the region by generous training subsidies and relocation assistance, and management easily recruited a skilled workforce for the new, high-paying jobs. The company's central works council helped to coordinate elections for a local works council, which established a good working relationship with management. In line with the policies across T-Online, the works council negotiated team-based incentives, strict limits on management's ability to remotely monitor calls, and regular pay increases.

After several years, T-Online sold this center to the U.S.-based subcontractor Sykes as part of a plan to outsource the majority of its call center work. The new company retained the existing workforce, who kept the terms of their former contracts for eighteen months. However, toward the end of that period, management gradually introduced individual performance-based pay and flexible scheduling. New employees were hired on short-term contracts, at two-thirds the pay of tenured agents. While agents continued to handle the same kinds of calls, they were expected 